\title{
Chronic non-A, non-B hepatitis: role of hepatitis C virus
}

\author{
R Iorio, S Guida, S Porzio, I Fariello, A Vegnente
}

\begin{abstract}
Thirty three consecutive children with chronic non-A, non-B hepatitis (NANBH) were studied during a four year period to evaluate clinical and histological features and the role of hepatitis C virus (HCV). All patients were asymptomatic. Thirteen $(39 \%)$ of them were anti-HCV positive. A history of parenteral exposure was significantly more frequent among anti-HCV positive $(69 \%)$ than antiHCV negative patients (15\%). Aminotransferase serum values were not statistically different between anti-HCV positive and anti-HCV negative patients. Unlike adults, cirrhosis was never found in the children studied. Our results suggest that chronic NANBH is, during childhood, an asymptomatic disease and that the prevalence of HCV infection is lower than in adults. As the majority of the children with chronic NANBH showed no evidence of $\mathrm{HCV}$ infection, it seems unwarranted to identify NANBH with HCV infection in children. The lack of cirrhosis in paediatric patients is probably related to a shorter duration of liver disease.
\end{abstract}

(Arch Dis Child 1993;68:219-22)

Non-A, non-B hepatitis (NANBH) accounts for $90 \%$ of post-transfusion hepatitis and for about $20-40 \%$ of cases of sporadic hepatitis. ${ }^{1}$ With the discovery of a test for antibodies to hepatitis $\mathrm{C}$ virus (HCV) it has been found that almost all post-transfusion hepatitis and about $50 \%$ of sporadic NANBH is caused by this virus. ${ }^{2-4}$ NANBH, including HCV infection, becomes chronic in more than $50 \%$ of infected individuals and in more than $20 \%$ of chronic cases histological evidence of cirrhosis is found. ${ }^{5}$ In adulthood, where intravenous drug use and sexual activity together have an important role in the spreading of NANBH, at least $40 \%$ of patients with NANBH have no known source of infection. ${ }^{6}$ On the other hand, scanty information is available about NANBH in childhood. Although studies have been performed concerning epidemiology ${ }^{7-9}$ and treatment ( $M$ RuizMoreno et al, work presented at the 24th Annual Meeting of the European Society for Paediatric Gastroenterology and Nutrition, London, June 5-7, 1991) of the disease, few data have been reported about clinical features, histology, and natural history in paediatric patients. The present study was undertaken with the aim of assessing the clinical picture of chronic NANBH in childhood and the role of $\mathrm{HCV}$, and to identify possible differences in epidemiology, clinical features, and histology between anti-HCV positive and anti-HCV negative children.

\section{Patients and methods}

We have studied 33 consecutive children (18 boys, 15 girls; mean age $7 \cdot 6$ years, range 1.4-13.2 years) with chronic NANBH who were seen in the department of paediatrics at the University of Naples during a four year period (1987-91). Diagnosis of chronic NANBH was made when high serum values of aminotransferases persisted for more than six months in the absence of known causes (that is infectious, metabolic, autoimmune, neoplastic, toxic, nonhepatic). In the patients studied the mean duration of chronic NANBH was four years (range 0.6-10.0 years). None of them had a history of acute hepatitis, 27 (82\%) showed raised aminotransferase serum values for the first time at routine check up before a minor surgical procedure (such as adenoidectomy or tonsillectomy); four (12\%) came to obervation for non-specific symptoms of liver disease (for example anorexia, asthenia, abdominal pain). Finally, two $(6 \%)$ were identified during family screening for viral hepatitis as their mothers showed evidence of NANBH and hepatitis C, respectively.

The mean age of patients at the first detection of hypertransaminasaemia was 3.6 years (range 0.3-9.7 years). In all patients clinical features and nutritional status were carefully evaluated. Weight was expressed as percentage of expected weight at a given height for the 50th centile. ${ }^{10} 11$ Height, measured with the Harpenden stadiometer, was expressed as percentage of expected height for age (that is, percent of 50th centile). ${ }^{10} 11$ The standards of the National Center for Health Statistics were used for assessment. ${ }^{12}$ According to Waterlow criteria, ${ }^{11} 13$ we have considered, in addition to normal, three possible degrees of malnutrition and three degrees of height stunting. In all patients liver function tests were carried out by standard methods, and antibodies to HCV were detected with a recombinant assay for anti-HCV (RIBA-2, Ortho Diagnostic Systems). The other causes of hypertransaminasaemia were excluded by conventional methods. As it has been reported that reduced IgA serum concentrations are frequently present in patients with chronic autoimmune hepatitis type- $2,{ }^{14}$ who are in turn anti-HCV positive in the $80 \%$ of cases, ${ }^{15}$ we have tested serum immunoglobulin concentrations in the patients studied with commercially available assays (Accra Assay RID Kits). In all patients ultrasound scanning was performed by 
using high resolution real time scanners. The following findings were recorded: liver echostructure and the size of liver, spleen, and portal vein. Liver histology, as recommended by an international group, ${ }^{16}$ was morphologically categorised in chronic persistent hepatitis when chronic inflammatory infiltrates were confined to the portal tracts with preserved lobular architecture and little or no fibrosis and with absent or slight piecemeal necrosis. Chronic active hepatitis was categorised when chronic inflammatory infiltrates extended from the portal tract into the parenchyma with piecemeal necrosis and eventually formation of intralobular septa. Furthermore, we have defined as minimal liver disease those cases in which there was only a minimal portal inflammatory infiltration with very mild hepatocyte necrosis. In 12 patients liver biopsy was not performed as their parents did not give consent. Epidemiological, clinical, histological, and laboratory features were compared between anti-HCV positive and anti-HCV negative patients. Statistical analysis was performed by the Student's $t, \chi^{2}$, and Fisher's exact tests.

\section{Results}

Thirteen children (39\%, nine boys, four girls, mean age $7 \cdot 9$ years, range $1 \cdot 4-12 \cdot 2$ years) out of 33 children with chronic NANBH showed serological evidence of $\mathrm{HCV}$ infection. The male:female ratio was $2 \cdot 25$ in anti-HCV positive patients and 0.8 in anti-HCV negative patients $(p=0 \cdot 15)$. Age at the diagnosis of chronic NANBH and type of onset were not statistically different between anti-HCV positive and antiHCV negative patients. None of the patients studied showed symptoms of liver disease, regardless of the HCV status. On physical examination, hepatomegaly was found in eight out of $13(61 \%)$ anti-HCV positive and in seven out of $20(35 \%)$ anti-HCV negative patients $(\mathrm{p}=\mathbf{0} \cdot 12)$; hepatosplenomegaly was found in one $(8 \%)$ anti-HCV positive and in one $(5 \%)$ anti-HCV negative patient $(p=0 \cdot 64)$. Nutritional status was satisfactory for all the patients and in fact their weight was above the $90 \%$ of that expected for their height (that is grade 0 malnutrition). All patients showed also a grade 0 for height stunting.

The route of infection of the patients studied is shown in table 1 . Nine (27\%) patients had received a blood transfusion before diagnosis of chronic NANBH was made (mean time 38 months, range 8-94 months). A history of blood

Table 1 Route to infection in 33 patients with chronic $N A N B H$ in relation to $H C V$ status

\begin{tabular}{lll}
\hline & $\begin{array}{l}\text { No (\%) } \\
\text { anti-HCV } \\
\text { positive } \\
(n=13)\end{array}$ & $\begin{array}{l}\text { No }(\%) \\
\text { anti-HCV } \\
\text { negative } \\
(n=20)\end{array}$ \\
\hline Blood transfusion & $7(54)^{*}$ & $2(10)^{*}$ \\
Parenteral exposure & $2(15)$ & $1(5)$ \\
Intrafamily transmission & $3(23)$ & $1(5)$ \\
Unknownt & $1(7)$ & $16(80)^{* *}$ \\
\hline * $\mathrm{p}=0 \cdot 009 ; * * \mathrm{p}=0 \cdot 00005$. & \\
+ Unknown=clinical history negative for the above mentioned \\
routes of infection.
\end{tabular}

transfusion was significantly more common among the anti-HCV positive patients, whereas in anti-HCV negative patients the source of infection was more commonly unknown. For three patients $(9 \%)$ a parenteral exposure was supposed, as they had undergone a surgical procedure and there was a close chronological correlation between surgery and detection of hypertransaminasaemia.

Intrafamilial transmission of hepatitis could be suggested in four (12\%) children: a vertical transmission was clearly shown only in one child and in another two cases such transmission could be supposed but not proved. Finally, a horizontal transmission was suggested in one child whose father was affected by chronic hepatitis $C$. In none of the remaining 62 parents and in none of the 36 siblings tested evidence of NANBH or HCV infection was found. At the time of the present study mean values of serum aspartate aminotransferase were 1.75 times the upper normal value (40 IU/l) (median $60 \mathrm{IU} / \mathrm{l}$, range 28-143 IU/1), and those of alanine aminotransferase were 3.3 times the upper normal value (40 IU/l) (median 83.5, range 19-250 IU/1), with no significant difference between anti-HCV positive and anti-HCV negative patients. Phases of normalisation of transaminasaemia were found in $17(85 \%)$ anti-HCV negative patients and in three $(18 \%)$ anti-HCV positive patients $(p=0.0005)$. The remaining anti-HCV positive patients showed, however, fluctuating values of transaminases, which never fell within the normal range. Twenty two patients (11 anti-HCV positive) were followed up for at least two years, and the profile of alanine aminotransferase serum concentrations showed no significant difference between initial and final vaues. The other tests of liver function were normal in all patients. Three $(23 \%)$ out of 13 anti-HCV positive patients had no detectable amount if IgA in peripheral blood and IgG and IgM serum concentrations were normal in all of them. Conversely, immunoglobulin concentrations were within the normal range in all antiHCV negative patients.

Ultrasound scanning confirmed the hepatomegaly and the hepatosplenomegaly found at clinical examination; no patient showed portal hypertension or significant changes in liver echostructure. Liver biopsy was performed after a mean time of 2.8 years (range $0.5-7.5$ years) from the diagnosis of chronic NANBH. With regard to clinical and biochemical features, no difference was found between biopsied and non-biopsied patients. As it has been reported that in NANBH liver damage is more severe in post-transfusion than in sporadic cases, ${ }^{17}$ the patients studied were grouped according to their route of infection. In table 2 the histological features of the patients biopsied are shown. Minimal liver disease was more frequent in antiHCV negative patients $(p=0.02)$ and chronic active hepatitis in anti-HCV positive patients $(p=0.04)$. Histological features, considered characteristic of NANBH, such as lymphoid follicles and periportal inflammation (P Gentilini et al. Hepatology 1991;14(4):69A, Abst 86), were never found, but fatty degeneration was found in six (two anti-HCV positive) patients. 
Table 2 Histological features in 21 children with chronic NANBH in relation to mode of transmission

\begin{tabular}{|c|c|c|c|c|c|c|}
\hline & \multicolumn{3}{|c|}{$\begin{array}{l}\text { No anti-HCV positive } \\
(n=10)\end{array}$} & \multicolumn{3}{|c|}{$\begin{array}{l}\text { No anti-HCV negative } \\
(n=11)\end{array}$} \\
\hline & Post-transfusion & Sporadic & Total (\%) & Post-transfusion & Sporadic & Total (\%) \\
\hline $\begin{array}{l}\text { Minimal liver disease } \\
\text { Chronic persistent hepatitis } \\
\text { Chronic active hepatitis }\end{array}$ & $\begin{array}{l}0 \\
1 \\
7\end{array}$ & $\begin{array}{l}0 \\
0 \\
2\end{array}$ & $\begin{array}{l}0^{*} \\
1(10) \\
9(90)^{*}\end{array}$ & $\begin{array}{l}1 \\
1 \\
0\end{array}$ & $\begin{array}{l}4 \\
0 \\
5\end{array}$ & $\begin{array}{l}5(45)^{*} \\
1(10) \\
5(45)^{* *}\end{array}$ \\
\hline
\end{tabular}

${ }^{*} \mathrm{p}=0.02 ;{ }^{* *} \mathrm{p}=0.04$

Altogether the liver lesions of our patients were not very specific of NANBH. Finally, considering our patients according to the route of infection, independently by the HCV status, liver damage was not statistically different between post-transfusion and sporadic cases.

\section{Discussion}

Previous epidemiological studies suggest that there are, in the world, approximately 100 million non- $A$, non-B carriers, including antiHCV positive subjects; for the majority no history of parenteral exposure is reported. ${ }^{1}$ In adulthood clinical features and outcome of $\mathrm{NANBH}$, in particular the high propensity of patients to develop cirrhosis, and the role of HCV infection are already known. ${ }^{4} 517$ Our study, performed in consecutive patients, demonstrates that in childhood chronic NANBH is in most cases an asymptomatic disease, so that its real prevalence in the paediatric population is probably underestimated. Furthermore, we have found that, unlike that seen in adults, ${ }^{3} \mathrm{HCV}$ plays a less important part as an aetiological agent of chronic NANBH. As the majority of the children with chronic NANBH showed no evidence of $\mathrm{HCV}$ infection, to identify $\mathrm{NANBH}$ with $\mathrm{HCV}$ infection appears, in childhood, unwarranted. Furthermore, considering that hepatitis A infection never becomes chronic, we think that the definition of 'chronic NANBH' for cases not related to $\mathrm{HCV}$ infection is incorrect, and we propose the term 'chronic non- $B$, non-C hepatitis'.

In our series, history of parenteral exposure was significantly more frequent among anti$\mathrm{HCV}$ positive than anti-HCV negative children. As in anti-HCV negative patients no marker of viral infection is available and the majority of our patients with chronic non-B, non-C hepatitis had an unknown source of infection, the viral nature of the disease might also be in doubt. Alternatively, chronic non- $B$, non- $C$ hepatitis could be caused by viral agent(s) that recognise a different mode of transmission. It is known that intrafamilial transmission does not play an important part in spreading NANBH, including HCV infection ${ }^{19-21}$; conversely, contrasting data about vertical transmission have been reported. ${ }^{22-25}$ The results of the present study show that both these modes of transmission play a minor part.

As far as liver histology is concerned: in the children studied severe lesions were not found, whereas in adults cirrhosis is present in $20 \%$ of cases. ${ }^{5}$ It is worth noting that histological features, reported as peculiar of NANBH in adults (for example, lymphoid follicles and periportal inflammation) were not found in the children studied. Considering anti-HCV positive patients collectively, the degree of liver damage was higher when compared with the group of anti-HCV negative subjects, but no peculiar histological feature distinguishing the two groups was identified. Moreover, our results do not confirm the presence of more severe liver damage in patients with post-transfusion hepatitis, as reported by other authors. ${ }^{17}$ The lack of signs of cirrhosis in the children studied cannot be considered a positive prognostic index for the outcome of the disease, as cirrhosis can develop afterwards also in the absence of severe liver damage in the early phases of the disease. ${ }^{17}$ In fact, in contrast with what had previously been reported in children with chronic $B$ hepatitis, in whom cirrhosis seems to be an early complication, ${ }^{26}$ in children with chronic NANBH the progression to cirrhosis might be related to the duration of disease. However, to support this hypothesis and to improve the knowledge of the natural history of the disease, longitudinal studies would be desirable.

We are however aware that such kind of study is at present ethically unjustifiable because of the promising results of interferon treatment. ${ }^{27-29}$ In conclusion, our study shows that chronic NANBH in children is characterised by a clinical picture and histological features that are different from those of adults. Therefore, it is interesting to study whether the minor histological lesions in children are dependent on the shorter duration of the disease or on a different age related host response to infection. Finally, as evidence of HCV infection has been found in anti-HCV negative patients by the polymerase chain reaction and detection of $\mathrm{HCV}$ antigen on liver tissue, ${ }^{4}$ the real role of $\mathrm{HCV}$ infection needs a further evaluation.

1 Rassam SW, Dusheiko GM. Epidemiology and transmission of hepatitis C infection. European Fournal of Gastroenterology and Hepatology 1991;3:585-91.

2 Choo QL, Kuo G, Weiner AJ, Overby LR, Bradley DW, Houghton $M$. Isolation of a cDNA clone derived from lood borne non-A non-B viral hepatitis genome. Sciemce 1989;244:359-62.

3 Kuo G, Choo QL, Alter HJ, et al. An assay for circulating antibodies to a major aetiologic virus of human non-A, non-B hepatitis. Science 1989;244:362-4.

4 Sherlock S, Dusheiko G. Hepatitis $C$ virus update [Editorial] Gut 1991;32:965-7.

5 Alter HJ, Purcell RH, Shih JW, et al. Detection of antibody to hepatitis $C$ virus in prospectively followed transfusion recipients with acute and chronic non-A, non-B hepatitis N Engl f Med 1989;321:1494-500.

6 Alter MJ, Sampliner RE. Hepatitis $C$ and miles to go before we sleep [Editorial]. N Engl \} Med 1989;321:1538-40.

7 Al-Faleh FZ, Ayoola EA, Al-Jeffry M, et al. Prevalence of antibody to hepatitis $\mathrm{C}$ virus among Saudi Arabian children a community-based study. Hepatology 1991;14:215-8. 
8 Vranckx R, Van Damme P. Hepatitis $C$ in institutionalized children. N Engl f Med 1990;323:64.

9 Bortolotti F, Tagger A, Cadrobbi P, Crivellaro C, Robero $\mathrm{NL}$, Alberti A. Antibodies to hepatitis $C$ virus in children with acute or chronic viral hepatitis. Lancet 1989;ii: 1162.

10 Sutphen JL. Growth as a measure of nutritional status. f Pediatr Gastroenterol Nutr 1985;4:169-81.

11 Waterlow JC. Some aspects of childhood malnutrition as a public health problem. $B M \mathcal{F} 1974$;iv:88-90.

12 Hamill PV, Drizd TA, Johnson CL, Reed RB, Roche AF, Moore WM. Physical growth: National Center for Health Statistics percentiles. Am f Clin Nutr 1979;32:607-29.

13 Waterlow JC. Classification and definition of protein-calorie malnutrition. BMF 1972; iii:566-9.

14 Mowat AP. Liver disorders in childhood. London: Butterworth, 1987:234.

15 Genesca J, Esteban J, Esteban R. Clinical associations of anti-HCV. European foumal of Gastroenterology and Hepato$\operatorname{logy} 1991 ; 3: 592-6$

16 De Groote J, Desmet VJ, Gedigk P, et al. A classification of chronic hepatitis. Lancet 1968;ii:626-8.

17 Mattsson L, Weiland $\mathrm{O}$, Glaumann $\mathrm{H}$. Chronic non-A, non-B hepatitis developed after transfusions, illicit selfinjections or sporadically. Outcome during long-term injections or sporadically. Outcome durin

18 Alter HJ. The hepatitis C virus and its relationship to the clinical spectrum of NANB hepatitis. Foumal of Gastroenterology and Hepatology 1990 (suppl) 1:78-94.

19 Hess G, Massing A, Rossol S, Schutt H, Clemens R, Meyer
Zum Buschentelde KH. Hepatitis $\mathrm{C}$ virus and sexual transmission. Lancet 1989;ii:987.

20 Ideo G, Bellati G, Pedraglio E, Bottelli R, Donzelli T, Putignano G. Intrafamilial transmission of hepatitis $\mathrm{C}$ virus. Lancet 1990;335:353.

21 Kamitsukasa H, Harada H, Yakura $M$, et al. Intrafamilial transmission of hepatitis C virus. Lancet 1989;ii:987.

22 Reesik HW, Wong VCW, Ip HMH, et al. Mother-to-infant transmission and hepatitis C virus. Lancet 1990;335:1216-7.

23 Tabor E. Non-A, non-B hepatitis as a cause of chronic hepatitis in children. Pediatr Infect Dis $\mathcal{F}$ 1989;8:477.

24 Giovannini M, Tagger A, Ribero ML, et al. Maternal-infant transmission of hepatitis $C$ virus and HIV infections: a possible interaction. Lancet 1990;335:1166.

25 Thaler MM, Park CK, Landers DV, et al. Vertical transmission of hepatitis C virus. Lancet 1991 ;i: 17.

26 Bortolotti F, Calzia R, Cadrobbi P, et al. Liver cirrhosis associated with chronic B virus infection in childhood. f Pediatr 1986;108:224-7.

27 Di Bisceglie AM, Hoofnagle JH. Therapy of chronic hepatitis C with alpha-interferon: the answer? or more questions? [Editorial] Hepatology 1991;13:601-3.

28 Davis GL, Balart LA, Schiff ER, et al. Treatment of chronic hepatitis C with recombinant interferon alpha. $N$ Engl $\mathcal{J}$ Med 1989;321:1501-6.

29 Di Bisceglie AM, Martin P, Kassianides C, et al. Recombinant interferon alpha therapy for chronic hepatitis C. $N$ Engl $\mathcal{F}$
Med 1989;321:1506-10 